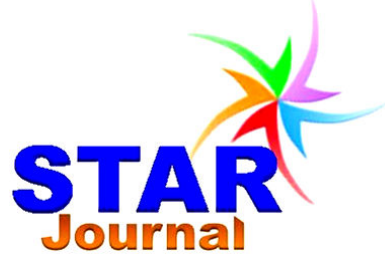

ISSN: 2226-7522(Print) \& 2305-3327 (Online) Science, Technology \& Arts Research Journal April-June 2013, 2(2): 135-139 www.starjournal.org Copyright@2013 STAR Journal. All Rights Reserved

Original Research

\title{
Economics of Groundnut Production in East Hararghe Zone of Oromia Regional State, Ethiopia
}

\author{
Gezahagn Kudama \\ ${ }^{1}$ Department of Agricultural Resource Economics Management, Wollega University, Post Box No: 38 \\ Shambu, Ethiopia
}

\begin{tabular}{|c|c|}
\hline & Article Information \\
\hline \multirow{3}{*}{$\begin{array}{l}\text { Groundnut is one the five widely cultivated oilseed crops in Ethiopia. However, the subsector } \\
\text { has been overlooked yet by development program interventions and analysis of its technical } \\
\text { as well as economic is lacking far behind. Hence, this study presents economic performance } \\
\text { of groundnut production in East Hararghe zone of Oromia regional state. It focuses on } \\
\text { technical relationships between groundnut output and different inputs, economic resources use } \\
\text { efficiency and cost benefit analysis. The result for the study is based on primary data } \\
\text { generated from } 86 \text { randomly sampled groundnut farm households at different stage by means } \\
\text { of structured and semi-structured questionnaire. From the total of seven explanatory variables } \\
\text { to be estimated by using Cobb- Douglas function, quantity of seed labor and livestock in } \\
\text { tropical livestock unit were significant at different significance level and they showed positive } \\
\text { effect on groundnut output. The economic efficiency of resource used showed the seed, } \\
\text { fertilizer and labor were underutilized and land was over utilized. }\end{array}$} & $\begin{array}{l}\text { Article History: } \\
\text { Received : 18-03-2013 } \\
\text { Revised : 07-06-2013 } \\
\text { Accepted : } 15-06-2013\end{array}$ \\
\hline & $\begin{array}{l}\text { Keywords: } \\
\text { Groundnut } \\
\text { Allocative } \\
\text { Economic } \\
\text { Technical Efficiencies }\end{array}$ \\
\hline & $\begin{array}{l}\text { *Corresponding Author: } \\
\text { Gezahagn Kudama } \\
\text { E-mail: } \\
\text { gkudama@gmail.com }\end{array}$ \\
\hline
\end{tabular}

\section{INTRODUCTION}

Groundnut is one the five widely cultivated oilseed crops in Ethiopia (Wijnands et al., 2009), Eastern Hararghe zone of Oromia region hold primary position in producing and supplying both domestic and export markets as compared to other parts of the nation (unpublished Ethiopia Export Promotion report, EEP 2004). Groundnut is grown under rain-fed and used for oil extraction, and for confectionary in Ethiopia. Moreover, it generates considerable cash income for several small scale producers and foreign exchange earnings through export for the country (Geleta et al., 2007).

Demand for groundnut is persistently increasing through time in the world markets. Future global demand for groundnut appears to be secure due to snack food markets in North America and the EU as well as in countries where groundnuts are a key ingredient in food preparation, such as Mediterranean, Indian and Asian cuisines (Rios and Jaffee, 2008). The recently franchised plumpy' nut (a peanut based nutritional product available for treatment of severe malnutrition in children age 6 to 24 months) operation in countries like Ethiopia offers additional market opportunities for groundnut producers (Pazderka and Emmott, 2010). Therefore, existing attention of market oriented agricultural policy of Ethiopian government, groundnut is promising income sources for producers.

Though few researches have conducted their research on groundnut, to date the attention of existing scholars seams to baized to the protection side of groundnut production in the country. However, the improvement of groundnut productivity is still stagnant in the country. Research result showed that groundnut farmers can produce groundnut yields of $2000 \mathrm{~kg} / \mathrm{ha}$ or more but the national average yield produced by the farmers in Ethiopia is considerably low, $1200 \mathrm{~kg} / \mathrm{ha}$ (Adugna et al., 1992). Similarly, Central Statistics Agency of Ethiopia (2009) survey report revealed that 1123 $\mathrm{kg} / \mathrm{ha}$ average yield of groundnut per year. Both early and leafs spot are the commonly existing diseases in Eastern party of Ethiopia and their effect can contribute to yield loss up to $65 \%$ (Riley, 1985). 
Gezahagn Kudama

Adugna (1992) incorporated poor cultural practices and lack of essential inputs in addition to diseases and pests as impediments for low yield of groundnut in Ethiopia. The first two factors he mentioned could lead to improper allocation of inputs and therefore it in turns calls for resources use efficiency improvement in groundnut production. After the work of Farrel (1957) efficiency of a firm comprises: technical, allocative and economic efficiency. Allocative efficiency refers to proportionately optimal utilization of inputs by farmers; whereas the technical efficiency is the capability of the farm to achieve the maximum possible output with available resources. Economic efficiency is the product of the two efficiencies.

In other hand, regardless of their types several studies on different crops from different parties of Africa independently underscore inefficient allocations of resources by farmers are the prominent problem for low productivities and their returns. Production efficiency study by Ogundari and Ojo (2006) on cassava in Nigeria, Taru et al. (2008) on groundnut in Nigeria and Aneani et al. (2011) on cocoa in Ghana are evidences. Therefore, this study is aimed to determine the technical, allocative, economic efficiencies and profitability of groundnut production in the study area. Finally, it is hoped that the study will help to narrow the wide research gap currently observed between resources availability and efficient utilization in groundnut production in East Hararghe zone of Oromia region, Ethiopia.

\section{MATERIALS AND METHODS}

This study was undertaken in East Hararghe zone of Oromia regional state in Ethiopia. It is located in Eastern part of the country at Latitude $8^{0}$ $30^{\prime} \mathrm{N}$ and longitude $40^{\circ} 40^{\prime} \mathrm{E}$ with a land area of about $17,935.40$ square kilometers. The population size of the area is estimated to $2,723,850$ (Wikimedia Foundation, 2010). The main socioeconomic activities in the districts are mixed farming (crop production and animal husbandry) non/offfarming. Moreover, the main crops grown in the area include maize, sorghum, groundnut, khat, coffee, haricot bean, sweet potatoes and pepper. Livestock husbandry includes cattle, sheep, goats, chicken camel and donkey. Groundnut production in the area accounts to $43.14 \%$ of total national output and it supports the livelihoods of estimated 78,450 households (CSA, 2009). The groundnut farming activities undertaken by households include farm establishment involving land clearing \& preparation as well as sowing of seeds; farm protection entailing weeding and control of pests and diseases; crop harvesting; and storage, transportation and sale of farm produce.
Sci. technol. arts Res. J., April-June 2013, 2(2): 135-139

Both primary and secondary sources of data were used. The secondary sources of data include: different reports, census data, and statistical documents whereas the primary source of data was entirely from field survey. Data were obtained through administration of structured and semistructured questionnaire to 86 randomly selected respondents for the study. The first stage involved random selection of two districts (Babille and Fedis) among six groundnut growing districts in East Hararghe zone. This was followed by random selection of two kebele administration, the list administration organ (Bishan Babille in Babille district and Risqi in Fedis district). In the third stage, based on the proportion of groundnut farmers of two districts, 32 and 54 respondents were randomly selected from Bishan Babille and Risqi kebele administrations to make a total sample of 86 all together. Data were collected on inputs, output, socioeconomic characters, and prices of groundnut farmers for the year of 2008/2009 cropping season.

\section{Data Analysis}

The all data collected in local measurements were converted into standard unit and the final analysis was computed with aid of Microsoft Excel and STATA version 10.

\section{Profitability Analysis}

In computing total cost production both variable and fixed costs were considered. Estimated value of family labors and land from own used in production were considered in terms of their opportunity costs of market wages and rental values respectively. In countries where purchasing agricultural land hardly exists but considerable tenancy, rental value of land probably provides a fairly good indication of the net value of production. Similarly, opportunity cost of rural labor measured in market wage paid of peak seasons can be accepted as the economic value of the rural labor (Gittinger, 1984). In a general form, the costs and returns analysis used in specified as below.

$$
\begin{gathered}
\mathrm{NFI}=\mathrm{GR}-\mathrm{TC} \\
\mathrm{TC}=\mathrm{TVC}+\mathrm{TFC}
\end{gathered}
$$

Where,

$\mathrm{NFI}=$ Net farm income in (ETB/ha)

$\mathrm{TC}=$ Total cost $($ Birr/ha)

$\mathrm{GR}=$ Gross revenue (Birr/ha)

TVC $=$ total variable cost (Birr/ha)

TFC $=$ total fixed cost (Birr/ha)

Production function analysis: Production function refers to the functional relationship that exists between physical inputs and physical output. In analyzing functional relationship between groundnut output and selected variables, the study employed Cobb Douglass production function. It is a widely 


\section{Gezahagn Kudama}

used model in similar studies (Aneani et al., 2011). Hence, it is worthwhile to make cross check the findings of the study with the earlier results. For this study it is specified in abstract term as given below:

$Y=A \cdot X_{1}^{\alpha_{1}} \cdot X_{2}^{\alpha_{2}} \cdot X_{3}^{\alpha_{3}} \cdot X_{4}^{\alpha_{4}} \cdot X_{5}^{\alpha_{5}} \cdot X_{6}^{\alpha_{6}} \cdot X_{7}^{\alpha_{7}} \cdot e^{U_{\iota}}$

Where,

$\mathrm{Y}=$ groundnut output of shelled in $(\mathrm{Kg})$;

$\mathrm{X}_{1}=$ age of farmers in years;

$\mathrm{X}_{2}=$ Farm size $(\mathrm{Ha})$;

$\mathrm{X}_{3}=$ Quantity of seed $(\mathrm{Kg})$;

$\mathrm{X}_{4}=$ Quantity of fertilizer $(\mathrm{Kg})$;

$\mathrm{X}_{5}=$ Quantity of labor input (man days);

$\mathrm{X}_{6}=$ Educational level of farmers in yearning school;

$\mathrm{X}_{7}=$ Livestock in tropical livestock unit (TLU);

$\mathrm{A}=$ Constant term;

$\mathrm{U}_{\mathrm{i}}=$ Error term

The linear transformation of the above equation by taking the natural logarithm of the function can be given as:

$$
\begin{gathered}
\ln \mathrm{Y}=\ln \mathrm{A}+\alpha_{1} \ln \mathrm{X}_{1}+\alpha_{2} \ln \mathrm{X}_{2}+\alpha_{3} \ln \mathrm{X}_{3}+\alpha_{4} \ln \mathrm{X}_{4} \\
+\alpha_{5} \ln \mathrm{X}_{5}+\alpha_{6} \ln \mathrm{X}_{6}+\alpha_{7} \ln \mathrm{X}_{7} \\
+\alpha_{8} \ln \mathrm{X}_{8}+\mathrm{U}_{\mathrm{i}}
\end{gathered}
$$

Parameters, $\alpha_{1, \ldots, \alpha_{7}}$ are estimated by OLS (Ordinary Least square) method. Prior expectation of all variables would be positive.

\section{Elasticity of Production}

Elasticity of production is the measure the effect of changes in the factor input on output. In CobbDouglas production function, the regression coefficients stand for the elasticities of the individual resources. The sum of these parameters indicates the nature of returns to scale.

If sum is equal to 1 , it indicates constant returns to scale; If sum is greater than 1 it shows increasing returns to scale and If sum is less than 1 it implies that decreasing returns to scale

\section{Resource Efficiency}

The estimated coefficients were used to compute the MVP and its ratio (R) with MFC used to determine the economic efficiency of resource used. The Marginal Value Product (MVP) of the employed resources was compared to determine the degree of efficiency in their use. The model was calculated as follows:

Where,

$$
\mathrm{R}=\mathrm{MVP} / \mathrm{MFC}
$$

$\mathrm{R}=$ efficiency ratio

MVP = marginal value product of variable inputs

$\mathrm{MFC}=$ marginal factor cost (price per unit inputs)
Sci. technol. arts Res. J., April-June 2013, 2(2): 135-139

MVP is the product of marginal physical product (MPP) and a unit price of groundnut (Y). MPP in turns computed as

$$
\begin{aligned}
& \mathrm{MPP}=\partial \mathrm{Y} / \partial \mathrm{X}_{i} \\
& \mathrm{MPP}=\alpha_{\mathrm{i}} \mathrm{Y} / \mathrm{X}_{\mathrm{i}}
\end{aligned}
$$

Where,

$Y=$ output of groundnut;

$\mathrm{X}_{\mathrm{i}}=$ individual inputs and

$\alpha_{\mathrm{i}}=$ output easticities

Interpretation of value of efficiency ratio $(R)$ is given as

If $R$ is less than 1 ; it indicates over utilization of employed resource.

If $R$ is greater than 1 ; it indicates under utilization of employed resource.

If $R$ is equal to 1 ; it shows the resource is efficiently used.

For optimal allocation of the resources the relative resource correction desired was designed as follows (Moses and Adebayo, 2007):

Where,

$$
D_{i}=\left(1-\left(M F C_{i} / M V P_{i}\right)\right) \times 100
$$

$D_{i}=$ absolute value of the percentage change in MVP of the $i^{\text {th }}$ resource;

$M F C i=$ marginal factor cost of the $i^{\text {th }}$ resource;

$M \mathrm{MP}_{\mathrm{i}}=$ marginal value product of the $\mathrm{i}^{\text {th }}$ resource .

\section{RESULTS AND DISCUSSION}

Technical efficiency of the resource use: the production function that was used to determine the nature of inputs - output relationship in groundnut production is shown in Table 1 . The $F$ ratio was significant at $1 \%$ probability level indicating that there is a significant linear relationship between the independent variables taken together and output of groundnut. The R- squared of 0.745 shows that $74.5 \%$ changes of groundnut production are explained by the various independent variables used in the model and the rest $25.5 \%$ changes is due to other determinants (Table, 1).

Of the total of seven independent variables entered to the model three variables were significant at different level. Whilst the intercept, seed and livestock in TLU were significant at $1 \%$ probability level, labor was significant at $10 \%$. All the variables included in the analysis were positive and in agreement with prior expectation. Coefficient of individual variable indicates elasticity of groundnut output. The result shows that $1 \%$ increase in quantity seed, labor and livestock in TLU leads to increase $0.739 \%, 0.291$ and $0.247 \%$ in groundnut output. 
Table 1: Cobb-douglas regression estimate for groundnut production.

\begin{tabular}{llccc}
\hline Variables & Coefficient & Standard Error & T-Value & P>t \\
\hline Age & 0.287 & 0.186 & 1.54 & 0.127 \\
Farm size & 0.033 & 0.182 & 0.18 & 0.857 \\
Seed & $0.739^{* * *}$ & 0.109 & 6.78 & 0.000 \\
Fertilizer & 0.020 & 0.018 & 1.11 & 0.268 \\
Labor & $0.291^{*}$ & 0.172 & 1.69 & 0.095 \\
Education & 0.015 & 0.011 & 1.35 & 0.181 \\
Livestock in Tropical & $0.247^{* * *}$ & 0.061 & 4.01 & 0.000 \\
livestock unit & -3.343 & 1.114 & -3.00 & 0.004 \\
Constant & & 86 & & \\
Number of observation & & 32.62 & & \\
F ( 7, 78) & & 0.000 & & \\
Probability > F & & 0.745 & & \\
$\mathbf{R}^{2}$ & & 0.723 & & \\
Adjusted $\mathbf{R}^{2}$ & & ${ }^{*}$ Significant at 10\% and ${ }^{* * *}$ Significant at 1\% &
\end{tabular}

The coefficient of labors was statistically significant at level of $1 \%$ and positive. The sign of the coefficient is in agreement with prior expectation and suggests that as the quantity of labor use increases the amount of output increases, keeping other variable constant. However, such relationship holds true if the available labor is efficiently allocated with other resources. The result of the study agrees with the findings of (Katungi et al., 2011; Taru et al., 2008).

The coefficient livestock in Tropical Unit (TLU) was statistically significant al level of $1 \%$ and positive. The result gives good reason for derived implication of livestock on groundnut output since the amount of farmyard manure added to groundnut farm dependence on the quantity of livestock the household own.
The sum of production elasticities amount to 1.61 , which reflects increasing returns to scale. In other words, a one percent increase in the usage levels of all inputs would result in a greater than one percent increase in output. Hence, the result indicates that factor inputs were not efficiently allocated.

Allocative and economic efficiency in resource use: the results of marginal physical product (MPP) and marginal value product (MVP) analysis of inputs utilization are provided in Table 2. Keeping other variables constant, the MPP result of individual input shows, an increase in kilogram of seed, fertilizer and man-days of labor would increase output by $8.76,2.63 \& 3.67 \mathrm{~kg} / \mathrm{ha}$ respectively. Similarly, MVP shows an increase in kilogram of seed, fertilizer and man-days of labor tend to increase revenue by Birr $56.04,16.86$ and 23.46 respectively.

Table 2: Estimated resources use efficiency in groundnut production.

\begin{tabular}{lcccccc}
\hline & Coefficient & MPP & MVP & UFC & MVP/UFC(R) & D in percent \\
\hline Age & 0.287 & & & & & \\
Farm size & 0.033 & 34.62 & 221.59 & 827.79 & 0.27 & -74 \\
Seed & 0.739 & 8.76 & 56.04 & 6 & 9.34 & 89 \\
Fertilizer & 0.020 & 2.63 & 16.86 & 6.42 & 2.63 & 62 \\
Labor & 0.291 & 3.67 & 23.46 & 20 & 1.17 & 15 \\
Education & 0.015 & & & & & \\
Livestock in TLU & 0.247 & & & & & \\
Returns to scale & 1.631 & & & & & \\
\hline
\end{tabular}

The ratios of MVP to MFC (R) of seed, fertilizer and labor inputs were greater than unity and it reveals all these inputs were underutilized on the farms in producing groundnut. Thus, optimum level allocation of these resources inquires $89 \%, 62 \%$ and $15 \%$ increment on existing quantity of seed, fertilizer and labor respectively. However, farm size was over-utilized due to the fact that its estimate was less than one and its use should be reduced by $74 \%$ to ensure efficient production.
Cost and return analysis: cost benefit analysis of groundnut production assessed in this study included all activities undertaken by producers through converting all local units into standard unit. However, the unit of account used in this paper is Birr, Ethiopian legal currency. Table 3 depicts that cost return computation of groundnut production per hectare of land. Accounting for $39.33 \%$ of a total cost labor found to be a leading cost. The analysis shows that $65.69,26.65$ and $7.67 \%$ of the total cost incurred per hectare by producers are allocated for 
Gezahagn Kudama

variable costs, fixed costs and other costs. Per hectare gross and net income amounted to Birr 6209.12 and 2052.02 respectively. Hence, the result
Sci. technol. arts Res. J., April-June 2013, 2(2): 135-139

indicates groundnut production was profitable enterprise.

Table 3: Estimated cost and return analysis for groundnut production.

\begin{tabular}{lll}
\hline Variable & Birr/ha & Percentage \\
\hline Seed & 557.56 & 12.84 \\
Fertilizer & 41.11 & 0.95 \\
Labor & 1666.52 & 38.36 \\
Draft power & 497.04 & 11.44 \\
Total variable cost (TVC) & 2762.23 & 63.59 \\
Fixed cost & & \\
Land cost & 827.79 & 19.06 \\
Depreciation & 279.92 & 6.44 \\
Interest at 7.5\% & 155.38 & 3.58 \\
Total fixed cost (TFC) & 1263.09 & 29.08 \\
Other cost & & \\
Package & 172.70 & 3.98 \\
Transportation & 145.98 & 3.36 \\
Total other cost (TOC) & 318.68 & 7.34 \\
Total cost (TVC+TFC+TOC) & 4344.00 & 100.00 \\
Gross farm income & 6209.12 & \\
Net farm income & 2020.50 & \\
\hline
\end{tabular}

\section{CONCLUSION}

This study revealed that groundnut production was profitable activity however there still unexploited potential to increase yield \& returns for groundnut farm households. Accordingly, the CobbDouglas production function result ensures positive relationship between groundnut output and quantity of seed, labor and livestock. Moreover, there exists allocative inefficiency of resources use. Whilst seed, fertilizer and labor were underutilized, groundnut farm was over utilized during the cropping season.

\section{ACKNOWLEDGEMENT}

I gratefully acknowledge the immense knowledge and insightful guidance of my adviser Dr. Ayalneh Bogale \& I would like to express my gratitude to Haramaya University for providing research grant.

\section{REFERENCES}

Adugna, W. (1992). Performance of elite groundnut varieties in Ethiopia. Proceedings of the $5^{\text {th }}$ regional groundnut workshop for Southern Africa. International crops research institute. Lilongwe, Malawi, pp. 21-24.

Aneani, F., Anchirinah, V.M., Asamoah M., Owusu-Ansah, F. (2011). Analysis of economic efficiency in cocoa production in Ghana. African Journal of Food Agriculture Nutrition and Development 11: 4507-4526.

CSA, (2009). Agricultural sample survey of area and production of crops of 2008/2009 in Ethiopia. Government annual report on area and production of crops, Addis Ababa, Ethiopia, pp. 1-128.

Farrel, M.J. (1957). Measurement of production efficiency. Journal of Royal Statistic Society 120:253-281.

Geleta, T., Purshotum K.S., Wijnand S., Tana T. (2007). Integrated management of groundnut root rot using seed quality. International Journal of Pest Management 53 - 57.
Gittinger, J.P. (1984). Economic analysis of agricultural project planning. World Bank, New York .

Katungi, E., Horna, D., Gebeyehu, S., Sperling L. (2011). Market access, intensification and productivity of common bean in Ethiopia. African Journal of Agricultural Research 6: 476-487.

Moses, J., Adebayo, E.F. (2007). Efficiency of factors determining rain fed rice production in Ganye local government area, Adamawa. Journal of Sustainable Development in Agriculture and Environment 20-30.

Ogundari, K., Ojo S.O. (2006): An examination of technical, economic and allocative efficiency of small farms, the case study of cassava farmers in Osun State of Nigeria. Journal of Centeral Eroupe Agriculture 7: 423-432.

Pazderka, C., Emmott, A. (2010). African groundnuts. procurement for development case study. London, pp. 1-15.

Riley, K. (1985). The oil crops network and groundnut improvement in North East Africa. Proceedings of international crops research institute for the semi-arid tropics. Lilongwe, pp. 141-144.

Rios Diaz, L.D., Jaffee, S. (2008). Standards, competitiveness \& Africa's groundnut exports to Europe. World Bank, Agriculture and Rural Development Discussion Paper 39. Washington, DC, pp. 1-80.

Taru, V.B., Kyagya, I.Z., Mshelia, S.I., Adebayo, E.F. (2008). Economic efficiency of resource use in groundnut production in Adamawa State of Nigeria. World Journal of Agricultural Sciences 4: 896-900.

Wijnands, J.H.M., Biersteker J., Van Loo E.N. (2009). Oil seed business opportunity in Ethiopia. Oil seed research report. Addis Ababa, Ethiopia.

Wikipedia. "Wikimedia Foundation, Inc." Wikimedia Foundation, Inc.web site. December 5, 2010. file:///F:/Misraq_Hararghe_Zone.htm (July 25, 2011). 